\title{
Serological Detection of Grapevine Associated Closteroviruses in Infected Grapevine Cultivars
}

\author{
Judit Monis and Richard K. Bestwick, Agritope, Inc., Research and Development Department, 8505 S.W. Creek- \\ side Place, Beaverton, OR 97008
}

\begin{abstract}
Monis, J., and Bestwick, R. K. 1997. Serological detection of grapevine associated closteroviruses in infected grapevine cultivars. Plant Dis. 81:802-808.

Western blot immunoassay and enzyme-linked immunosorbent assay using different monoclonal antibodies (MAb) and polyclonal antisera (PA) revealed mixed infections of serologically related and unrelated grapevine leafroll associated viruses (GLRaVs) and grapevine corky bark associated virus $(\mathrm{GCBaV})$ in symptomatic grapevines. A PA designated rootstock-scion incompatibility (RSI)-24 kDa, grapevine corky bark PA, and GLRaV-2b MAb reacted to polypeptides of approximately $24 \mathrm{kDa}$ isolated from grapevines exhibiting rootstock-scion incompatibility, leafroll, and corky bark disease symptoms, suggesting that these isolates are infected with closely related viruses. A PA designated GLRaV-2 US detected virus specific polypeptides of $38,37,36$, and $24 \mathrm{kDa}$, while a polyclonal antiserum designated GLRaV-2 FR detected a single virus-specific polypeptide of approximately $24 \mathrm{kDa}$. The reactivity of GLRaV-2 US to various polypeptides suggests that the immunogen used to produce this antiserum was a mixture of viruses. Apical meristems were excised and cultured to eliminate the infection of viruses in the grapevines showing RSI symptoms and in the cultivar French Colombard infected with GLRaV1. The elimination of these viruses was confirmed by Western blot assay. These studies show that the Western blot assay can be used to detect and differentiate grapevine disease-associated closteroviruses.
\end{abstract}

Grapevine leafroll (LR) and corky bark (CB) diseases occur wherever grapevines are grown and are associated with undesirable viticultural effects which include delayed ripening of fruit, reduced yield, altered fruit pigmentation, and reduced accumulation of sugar $(6,24)$. Rootstockscion incompatibility (RSI) is a disease syndrome characterized by incompatibility at the graft union resulting in slow death of the scion (5).

The etiology of LR disease is not clear. Different kinds of virus particles have been associated with symptomatic variants of LR disease (24), but only closterovirus-like particles have been consistently associated with this disease (14). Viruses found in LR infections are designated grapevine leafroll associated viruses (GLRaVs). Other closterovirus-like particles designated as grapevine corky bark associated viruses (GCBaVs) were found in $\mathrm{CB}$ infections (20). Many cultivars often carry latent infections of grapevine viruses and are asymptomatic until they are grafted onto a susceptible rootstock (5).

Several laboratories have purified closterovirus-like particles from diseased vines and prepared monoclonal antibodies $(\mathrm{MAb})$ and polyclonal antisera (PA)

Corresponding author: J. Monis

E-mail: jmonis@epitope.com

Accepted for publication 9 April 1997.

Publication no. D-1997-0529-04R

(๑) 1997 The American Phytopathological Society
$(8,10,11,20,26)$. Using sodium dodecyl sulfate-polyacrylamide gel electrophoresis (SDS-PAGE), the molecular weights of GLRaV-1, -3, -4, and GCBaV coat proteins have been reported to be approximately 38 , $43, \quad 36$, and $26 \mathrm{kDa}$, respectively $(8,10,11,20)$. Two different molecular weights (circa 26 and $36 \mathrm{kDa}$, respectively) have been reported for the coat proteins of the United States and French GLRaV-2 isolates $(2,26)$, suggesting that these are different viruses. In addition, Gugerli and Ramel (8) reported that a MAb designated MCA 29-1 (prepared with GLRaV-2b) reacted to a polypeptide of approximately $26 \mathrm{kDa}$ in a Swiss virus isolate.

With the exception of GLRaV-2, GLRaV-2b, and GCBaV, the reported mass of the capsid proteins of grapevine associated closterovirus-like particles are greater than expected for closterovirus capsid proteins (circa 22 to $26 \mathrm{kDa}$ ). This information suggests that these viruses could represent a new virus group.

Presently, LR is diagnosed by biological indexing and enzyme-linked immunosorbent assay (ELISA), while CB is diagnosed by biological indexing only. Symptom evaluation of an indicator host is subjective, non-specific, and time consuming. Discrepancies have been found between ELISA and woody indicator tests $(18,22)$. GLRaV-1 and GLRaV-3 were detected by ELISA and Western blotting in previously registered foundation material that had been determined to be virus free by biological indexing $(17,18)$. ELISA has also been unreliable, since the poor quality of the PA available would yield a positive reaction in response to non-specific reactivity or infection with one or more viruses. Furthermore, the distribution of GLRaVs is variable in vegetatively grown and dormant grapevines (18), making the choice of sampling strategies critical to successful detection of grapevine associated closteroviruses.

In this study we show that a Western blot (WB) assay using various antibodies permits reliable and accurate detection of viral polypeptides, and hence diagnosis of viruses associated with RSI, leafroll, and corky bark diseases. Furthermore, the WB assay has allowed the characterization of $\mathrm{PA}$ reactive to several virus isolates.

\section{MATERIALS AND METHODS}

Plant materials. The isolates used in this study are described in Table 1. Biological indexing confirmed the infection status of all positive and negative controls, with the exception of the French Colombard (FC/2) cultivar that tested negative by grafting onto indicator hosts but tested positive using ELISA (18). Dormant cuttings of LR 101, LR 102, LR 105, LR 106, LR 109, and CB 100 (4) were provided by Deborah Golino (University of California, Davis); positive controls designated in our laboratory as LR-A, LR-B, LR-C, and LR$\mathrm{D}$ were provided by Adib Rowhani (University of California, Davis). Grapevines with RSI, and field selections that reacted with corky bark and GLRaV-2b antibodies (17) were obtained from California vineyards. The negative controls (FPMS certified rootstock cultivars) were provided by Vinifera, Inc. (Petaluma, CA). Cuttings from the above-mentioned vines were rooted and grown in our research greenhouse in Beaverton, Oregon. The vines were grown from March until December at approximately 25 to $28^{\circ} \mathrm{C}$ and supplemented with $4 \mathrm{~h}$ of light. Vines were allowed to go dormant during the period between December and March in a cold frame greenhouse (no temperature or light adjustments).

Serological reagents. The PA and MAb used in this study are described in Table 2. GLRaV-2 US, -3, -4, and GCBaV PA were cross-absorbed (7) with virus-free Vitis riparia Gloire (RG) extracts prior to immunoglobulin purification by protein A chromatography and conjugation with alkaline phosphatase (9). GLRaV-1 MAb and alkaline phosphatase-labeled GLRaV-1 $\mathrm{MAb}$ used in double antibody sandwich 
ELISA (DAS-ELISA) were purchased from BIOREBA AG (Basel, Switzerland). Phosphatase-labeled goat anti-rabbit and goat anti-mouse IgG used in the WB assay were purchased from Kirkergaard \& Perry Laboratories, Inc. (Gaithersburg, MD).

Production of polyclonal antisera. Polyclonal antisera were produced in duplicate New Zealand rabbits using gel purified SDS-PAGE viral coat proteins. Concentrated extracts from healthy RG grapevine were used to immunize rabbits. The RG extracts were verified to be free of viruses using immunosorbent electron microscopy (ISEM), ELISA, and WB.

GLRaV-1 and RSI-associated virus particles (17) were purified from FC/2 and RSI-symptomatic grapevine cultivars, respectively. Healthy RG extracts were concentrated with the same method used for virus purification. Briefly, stem and petiole tissue were cut in small portions and ground in liquid nitrogen, the tissue was homogenized in virus extraction buffer, and the virus or host proteins were concentrated by two series of differential centrifugation (25). Preparative SDSPAGE were used to separate the viral proteins from contaminating host proteins. Purified virus preparations $(250 \mu \mathrm{l})$ were resolved by SDS-PAGE (14\% polyacrylamide) (13). The region of the gel containing the viral capsid protein was identified by blotting one lane of each slab gel and testing the reactivity of the transferred polypeptides with anti-GLRaV-2 US PA and GLRaV-1 MAb (38 kDa) or antiGCBaV PA and GLRaV-2b (24 kDa) in WBs. The WB was aligned with the remaining lanes of the gel and the region corresponding to the 24 or $38 \mathrm{kDa}$ polypeptide bands were excised and eluted using an Elutetrap apparatus (Schleicher \& Schuell, NH). To ensure purity of the protein preparation, the eluted protein was run in a second SDS-PAGE and eluted a second time. The identity of the purified proteins was verified by WB using GLRaV-2 US PA and GCBaV PA before the rabbits were immunized; the PA were used in the WB because they would have revealed the contamination of host proteins in the preparation if present. Healthy RG extracts were used as a negative control. A single protein band of 24 or $38 \mathrm{kDa}$ was observed in all protein preparations of RSI and FC/2, respectively. Multiple bands observed in the healthy extract lanes reacted with GLRaV-2 US and GCBaV PA.

Prior to immunizations, rabbits were bled for pre-immune sera. Rabbits that had the lowest reactivity to healthy grapevine extracts were chosen for immunizations with gel-purified $38-\mathrm{kDa}(\mathrm{GLRaV}-1)$ and 24-kDa (RSI) polypeptides and concentrated extracts of healthy proteins. All protein extracts were emulsified using complete Freund's adjuvant prior to primary immunizations (9). Three additional injections containing Freund's incomplete adjuvant were performed 3,6 , and 9 weeks after the primary injection. Test bleeds were taken 1 week after each booster injection to determine the reactivity of the antiserum to the virus and plant protein extracts using the Western blot assay. The total serum was collected 1 month after the final booster injection. The antisera produced will be referred to as RSI-24 $\mathrm{kDa}$, GLRaV-1, and RG PA.

Table 1. Virus-infected and noninfected grapevine cultivars

\begin{tabular}{lrr}
\hline Isolate designation & Grapevine variety & Symptoms on indicator \\
\hline LR A & Unspecified field selection & Leafroll \\
LR B & Cabernet Sauvignon & Leafroll \\
LR C & Italia & Leafroll \\
LR D & Cabernet Sauvignon & Leafroll \\
LR 101 & Thompson Seedless & Leafroll \\
LR 102 & Thompson Seedless & Leafroll \\
LR 105 & Teroldigo-1 & Leafroll \\
LR 106 & Thompson Seedless & Leafroll \\
LR 109 & Thompson Seedless & Leafroll \\
FC/2 & French Colombard & None \\
RSI & Malbec & Incompatibility \\
CB100 & Semillion & Corky bark \\
SJ & Unspecified field selection & Incompatibility/corky bark \\
MBF & Merlot & Incompatibility \\
PS & Petit Shirah & Incompatibility \\
PS3 & Petit Shirah & Leafroll/incompatibility \\
Healthy & Vitis riparia Gloire & None \\
Healthy & Couderc 3309 & None \\
Healthy & Kober 5BB & None \\
\hline
\end{tabular}

Table 2. Source of serological reagents

\begin{tabular}{lrc}
\hline Antibody & \multicolumn{1}{c}{ Source } & Reference \\
\hline GLRaV-1, MAb a $^{\mathrm{a}}$ & & 8 \\
GLRaV-1, PA & BIOREBA AG & Agritope, Inc. \\
GLRaV-2, US PA & This report \\
GLRa-2, FR PA & D. Gonsalves, Cornell University & 2 \\
GLRaV-2b, MAb & Sanofi Diagnostics Pasteur & 26 \\
RSI-24 kDa, PA & P. Gugerli, Nyon Experimental Station, Switzerland & 8 \\
GLRaV-3, MAb & Agritope, Inc. & This report \\
GLRaV-3, PA & D. Gonsalves, Cornell University & 10 \\
GLRaV-4, PA & D. Gonsalves, Cornell University & 25 \\
Black Spanish, PA & G. Pietersen, Plant Protection Res. Institute, South Africa & 11 \\
GCBaV, PA & D. Gonsalves, Cornell University & 21 \\
Healthy, PA & Agritope, Inc. & 20 \\
\hline
\end{tabular}

a MAb, monoclonal antibodies.

${ }^{\mathrm{b}} \mathrm{PA}$, polyclonal antiserum.

Table 3. Enzyme-linked immunosorbent assay (ELISA) reactivity of virus isolates

\begin{tabular}{lcccc}
\hline & \multicolumn{5}{c}{ Antibodies $^{\mathrm{a}}$} \\
\cline { 2 - 5 } Virus isolates & GLRaV-1 & GLRaV-2 & GLRaV-3 & GLRaV-4 \\
\hline FC/2 & $3+^{\mathrm{b}, \mathrm{c}}$ & + & - & - \\
LR A & $3+$ & + & - & - \\
LR B & $2+$ & + & - & - \\
LR 102 & $3+$ & $2+$ & - & - \\
LR 105 & $3+$ & + & $4+$ & - \\
RSI & - & - & - & - \\
LR C & - & - & $4+$ & - \\
LR 101 & - & - & + & - \\
LR 109 & - & - & $3+$ & + \\
LR D & - & - & - & + \\
LR 106 & - & - & - & - \\
Healthy & $-{ }^{\mathrm{d}}$ & - & - & - \\
\hline
\end{tabular}

a The DAS-ELISA was performed with GLRaV-1 monoclonal antibodies (MAb), GLRaV-2 US polyclonal antiserum (PA), GLRaV-3 PA/MAb, and GLRaV-4 PA.

b The sample readings were scored in relation to the ratio of the $A_{405}$ of each sample and $2 \times$ the reading of the healthy negative control. The following scores, $(-),(+),(2+),(3+),(4+)$ were assigned to each treatment with a ratio of less than 1 (no reactivity), 1 to $2.499,2.5$ to $3.499,3.5$ to 4.499 , and above 4.5 , respectively.

${ }^{\mathrm{c}}$ The $(+) A_{405}$ (average of $4-10$ wells) of infected extracts were $2.376,1,711,2.206$, and 0.728 for ELISA using GLRaV-1, $-2,-3$, and -4 antibodies, respectively.

d The (-) $A_{405}$ (average of 10 wells) healthy extracts were $0.295,0.399,0.251$, and 0.271 for ELISA using GLRaV-1, $-2,-3$, and -4 antibodies, respectively. 


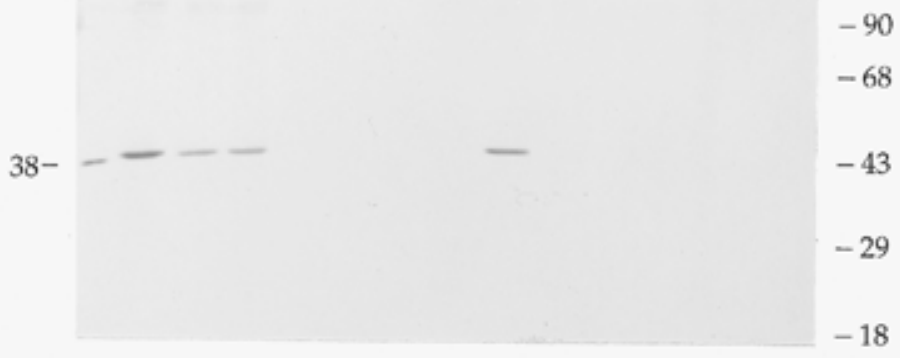

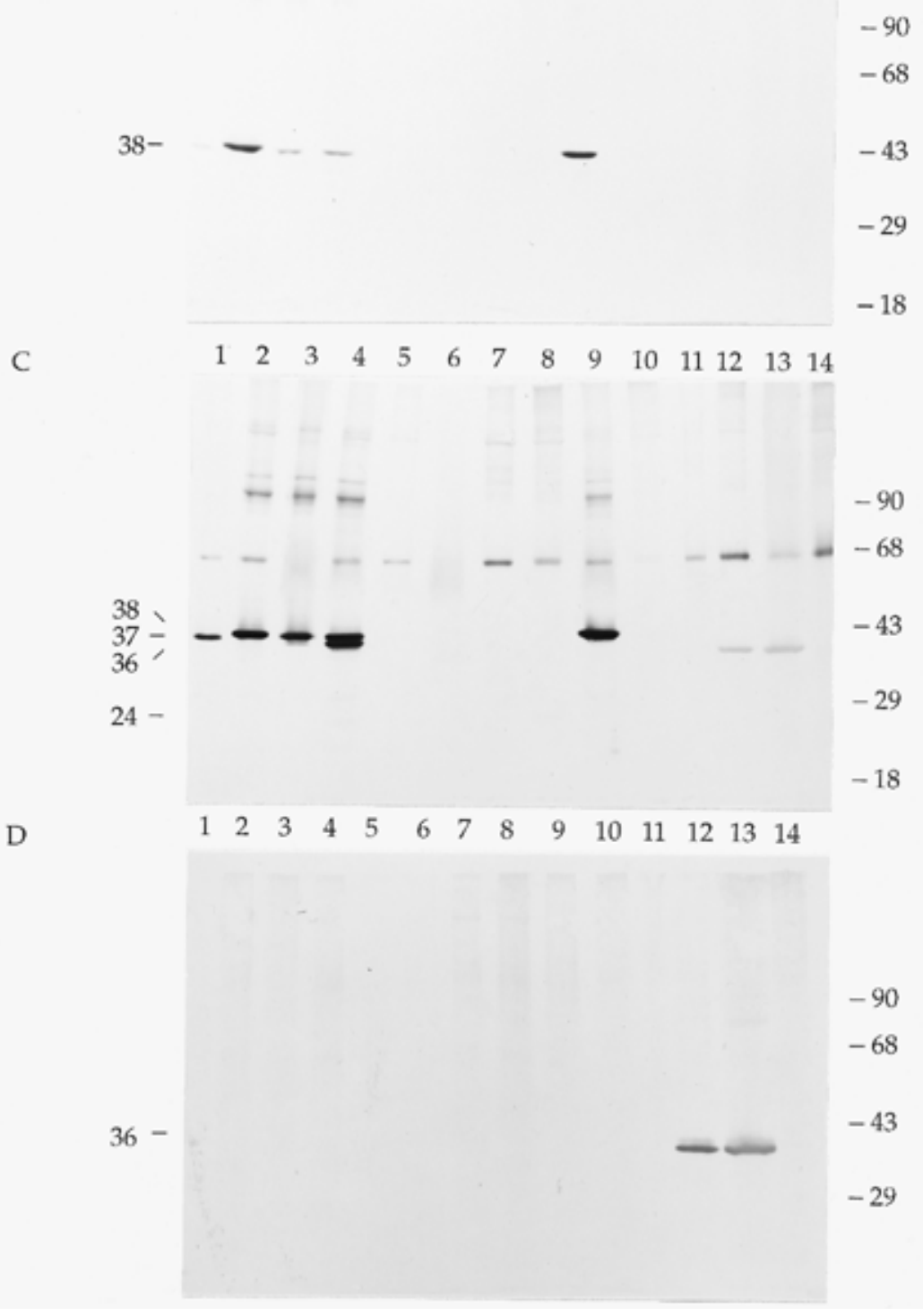

Fig. 1. Western blot assay of protein extracts using the following: GLRaV-1 PA (A); GLRaV-1 MAb (B); GLRaV-2 US PA (C); GLRaV-4 PA (D). The grapevine cultivars or isolates analyzed are: lanes 1, FC/2; lanes 2, LR-A; lanes 3, LR-B; lanes 4, LR 102; lanes 5, RSI; lanes 6, SJ; lanes 7, CB 100; lanes 8, LR 109; lanes 9, LR 105; lanes 10, LR 101; lanes 11, LR-C; lanes 12, LR-D; lanes 13, LR 106; lanes 14, healthy. The molecular weight of size markers and the viral specific proteins are indicated on the sides of each blot.
ELISA. The double antibody sandwich enzyme-linked immunosorbent assay (DAS-ELISA) was performed in duplicate wells for each sample as previously described (18) using GLRaV-1, -2, -3, and -4 antibodies.

Grapevine stem and petioles samples were collected from the bottom of the vine (18) and extracted with a tissue pulverizer (KLECO, Visalia, CA) at 1:5 (wt/vol) with $0.5 \mathrm{M}$ Tris- $\mathrm{HCl} \mathrm{pH} 8.2,143 \mathrm{mM} \mathrm{NaCl}, 1 \%$ polyethylene glycol (MW 8000), $2 \%$ polyvinyl pyrrolidone (MW 40,000), and $0.05 \%$ Tween-20. Ground samples were occasionally stored at $-20^{\circ} \mathrm{C}$ prior to ELISA tests. The sample tests were generally incubated for $2 \mathrm{~h}$ at room temperature with substrates, but some experiments required overnight incubations at $4^{\circ} \mathrm{C}$. The microtiter plates were read at an absorbance of $405 \mathrm{~nm}$.

Initial ELISA tests were performed with the antibodies described above to determine the infection status of each virus isolate. The threshold value for a positive ELISA reading was arbitrarily determined to be two times the average $A_{405}$ value of the healthy control ( 2 to 6 wells). The sample readings were scored in relation to the ratio of the $A_{405}$ of each sample and two times the $A_{405}$ reading of the healthy negative control. The following scores, $(-)$, $(+),(2+),(3+)$, and $(4+)$, were assigned to each treatment with a ratio of less than 1 (not infected), 1 to $2.499,2.5$ to $3.499,3.5$ to 4.499 , and above 4.5 , respectively (18).

Western blot assay. Samples for the WB assay were collected from stems and petioles of actively growing greenhouse plants (Monis and Bestwick, 1996) and prepared essentially as described by Zee et al. (25). The viral proteins were resolved by SDS-PAGE (10\% polyacrylamide) (13) and transferred electrophoretically to nitrocellulose membranes (23). The blots were incubated in $0.02 \mathrm{M}$ Tris $\mathrm{pH} 6.5$, with 0.5 M sodium chloride (TBS), containing 5\% nonfat dry milk, and $0.03 \%$ Tween-20 (blocking buffer) for $1 \mathrm{~h}$ at room temperature. Each of the antibodies described in Table 2 were added individually to the blocking buffer and incubated with replica blots for $1 \mathrm{~h}$ at room temperature. The membranes were washed (three times for 15 min) with TBS containing 3\% nonfat dry milk and $0.03 \%$ Tween-20 and incubated for $1 \mathrm{~h}$ with alkaline phosphatase conjugated goat anti-rabbit or goat antimouse IgG diluted 1:2000 in blocking buffer. The membranes were washed as described above, except that the final wash was performed with TBS. Immuno-reactive proteins were visualized using an NBT/BCIP development solution (Kirkergaard \& Perry Laboratories, Inc.)

Excision and culture of apical meristems. For in vitro propagation, $1-\mathrm{cm}$ nodal sections of vegetatively growing stems were surface sterilized and grown in initiation and propagation media $(12,19)$ under 
$16 \mathrm{~h}$ light. For virus elimination, approximately $0.5 \mathrm{~mm}$ apical meristems with 1 to 2 leaf primordia were excised and placed in solid medium (12). The regenerated meristems were sub-cultured at least once a month in propagation media (19). The infection status of the regenerated grapevine plantlets was determined using WB. The tissue-culture-grown plantlets were acclimated in the greenhouse and tested again to confirm the lack of virus infection with the WB assay using the RSI-24 kDa, GLRaV-1, and RG PA.

\section{RESULTS}

Production of polyclonal antisera to GLRaV-1, RSI-24 kDa, and proteins from healthy plants. The GLRaV-1 PA and RSI-24 kDa PA reacted with polypeptides of the expected molecular weight in FC/2 and RSI-infected material, respectively. The antiserum specific to RG protein extracts reacted with several polypeptides in healthy and virus infected grape extracts in WB assays.

Serological cross-reactivity of virus isolates. ELISA results are summarized in Table 3. Several virus isolates reacted with one or more of the antibodies used in this study. For example, LR-A, LR-B, and LR 102 reacted with GLRaV-1 MAb and GLRaV-2 US PA; LR 105 reacted with GLRaV-1 MAb, GLRaV-2 US PA, and GLRaV-3 PA. Extracts from healthy RG, Kober 5BB, and Couderc 3309 cultivars did not react specifically in ELISA or WB to any of the antibodies described in Table 2.

Western blot immunoassay. Extracts of grapevines were analyzed by WB using the antibodies described in Table 2. GLRaV-1 PA and GLRaV-1 MAb reacted with a single viral-specific polypeptide of circa 38 $\mathrm{kDa}$ in extracts from $\mathrm{FC} / 2$, LR-A, LR-B, LR 102, and LR 105 isolates (Fig. 1A and B, lanes 1-4, 9).

Using GLRaV-2 US PA, a polypeptide band of circa $38 \mathrm{kDa}$ was detected in extracts from FC/2, LR-A, LR-B, LR 102, and LR 105 viral isolates (Fig. 1C, lanes 1$4,9)$; note that in addition to the polypeptide of circa $38 \mathrm{kDa}$, a faint lower molecular weight band was observed in extracts from LR-B. WB performed with gels that had been run for a longer period of time with LR-B extracts clearly showed a doublet of circa 37 to $38 \mathrm{kDa}$ (not shown). In addition to the doublet of circa 37 and $38 \mathrm{kDa}$, the GLRaV-2 US PA recognized faintly a polypeptide of circa 24 $\mathrm{kDa}$ in extracts from LR 102 isolate (Fig. 1C, lane 4), and one viral specific polypeptide of approximately $36 \mathrm{kDa}$ in LR-D and LR 106 isolates (Fig. 1C, lanes 12 and 13). Crude GLRaV-2 US PA showed stronger reactivity to the $24 \mathrm{kDa}$ polypeptide in LR 102 extracts (not shown). The GLRaV-2 US PA reacted to a number of other non-viral polypeptides (predominantly of circa $68 \mathrm{kDa}$ ).
The GLRaV-4 PA (Fig. 1D) reacted with a single viral polypeptide of circa $36 \mathrm{kDa}$ in extracts from LR-D and LR 106 extracts (Fig. 1D, lanes 12-13).

The GLRaV-2b MAb, RSI-24 kDa PA, and $\mathrm{GCBaV}$ PA detected a virus-specific polypeptide of circa $24 \mathrm{kDa}$ in extracts from LR 102, RSI, SJ, CB 100, LR 109, LR 101, and LR-C (Fig. 2A, B, and C; lanes 4-8, 10-11). An additional polypeptide of circa $26 \mathrm{kDa}$, the significance of which is not known, could be seen in extracts from the LR 109 isolate (Fig. 2B, 8). This 26-kDa polypeptide was not observed in every virus preparation or WB assay performed using the same virus isolates. A doublet of circa 29 to $30 \mathrm{kDa}$ and other polypeptides of circa $40 \mathrm{kDa}$ and larger than $90 \mathrm{kDa}$, presumably of plant origin, were detected with GCBaV PA (Fig. 2C, lanes 2, 4-5, 7-8, 10, 12-14). Additional, field selections grown in the Napa Valley in California reacted to the RSI-24 $\mathrm{kDa}$, GLRaV-2b, and GCBaV antibodies, include the Merlot and Petit Shirah cultivars (Table 4). The GLRaV-2 FR PA reacted to a single polypeptide of circa $24 \mathrm{kDa}$ from extracts of LR 102, RSI, SJ, CB 100, LR
A

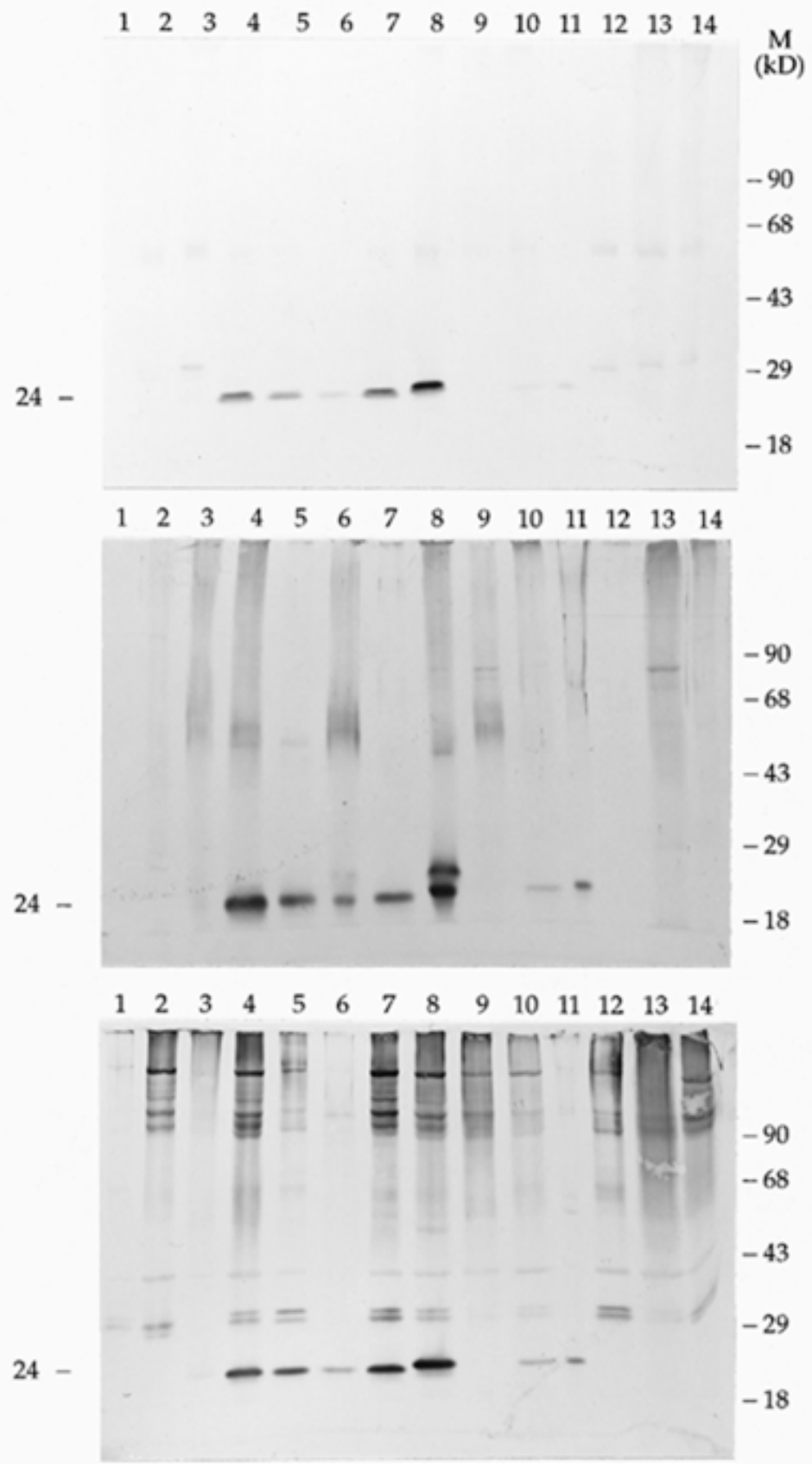

Fig. 2. Western blot assay of protein extracts using the following: GLRaV 2b (A); RSI-24 kDa PA (B); GCBaV PA (C); GLRaV-2 FR PA (D). The grapevine cultivars or isolates analyzed are: lanes 1, FC/2; lanes 2, LR-A; lanes 3, LR-B; lanes 4, LR 102; lanes 5, RSI; lanes 6, SJ; lanes 7, CB 100; lanes 8, LR 109; lanes 9, LR 105; lanes 10, LR 101; lanes 11, LR-C; lanes 12, LR-D; lanes 13, LR 106; lanes 14, healthy. The molecular weight of size markers and the viral specific proteins are indicated on the sides of each blot. 
109, LR 101, and LR-C isolates (Fig. 3). The reactivity of the GLRaV-2 FR PA was weak even when low dilutions of the antiserum (1:50) were used in the WB assay.

A virus-specific polypeptide of circa 43 $\mathrm{kDa}$ was detected by GLRaV-3 MAb (Fig. 4A) and GLRaV-3 PA (not shown) in extracts from LR 109, LR 105, LR 101 and LR-C isolates (Fig. 4A, lanes 8-11). The Black Spanish PA, which reacts with GVA, specific polypeptides extracted from most of the viral isolates tested (Fig. 4B). A polypeptide of circa $38 \mathrm{kDa}$ was detected in extracts from FC/2, LR-A, LR-B, LR 102, and LR 105 (Fig. 4B, lanes 1-4, 9) and another polypeptide of circa $24 \mathrm{kDa}$ can be seen in extracts from LR 102, RSI, SJ, and CB100 (Fig. 4B, lanes 4-8); The same antiserum reacted with polypeptides of circa $43 \mathrm{kDa}$ from LR 109, LR 105, LR GLRaV-1, -2 and -3 (21), bound to virus-

101, and LR-C (Fig 4B, lanes 8-11). A polypeptide (circa $30 \mathrm{kDa}$ ) was also seen in some extracts (Fig. 4B, lanes 1-14); it may be similar to one of the doublet bands seen in Fig. 2C and 4C. The PA prepared with proteins from $\mathrm{RG}$ healthy grapevine bound to presumably plant polypeptides from healthy (Fig. 3C, lane 14) and infected grapevine material (Fig. 4C, lanes 113). The results of the antibody reactivity of the different viral isolates are summarized in Table 4.

Virus elimination by apical meristem culture. The 38- and 24-kDa polypeptides associated with GLRaV-1 and RSI were not present in explants propagated from regenerated apical meristems excised from the GLRaV-1 infected FC/2 cultivar and RSI when analyzed using WB with GLRaV-1 and RSI-24 kDa PA (not shown). In addition, the RG PA detected the same

Table 4. Western blot reactivity of virus isolates

\begin{tabular}{|c|c|c|}
\hline Isolate & Antibodies & Polypeptide size \\
\hline$\overline{\mathrm{FC}} / 2$ & GLRaV-1 ${ }^{\mathrm{a}}, \mathrm{GLRaV}-2 \mathrm{US}^{\mathrm{b}}$ & $38 \mathrm{kDa}$ \\
\hline LR A & GLRaV-1a ${ }^{\mathrm{a}}$ GLRaV-2 US ${ }^{\mathrm{b}}$ & $38 \mathrm{kDa}$ \\
\hline LR B & GLRaV-1 ${ }^{\mathrm{a}}, \mathrm{GLRaV}-2 \mathrm{US}^{\mathrm{b}}$ & $38 \mathrm{kDa}$ \\
\hline & GLRaV-1 ${ }^{\mathrm{a}}, \mathrm{GLRaV}-2 \mathrm{FR}^{\mathrm{b}}, \mathrm{GLRaV}^{-2} \mathrm{US}^{\mathrm{b}}$, & \\
\hline LR 102 & GLRaV-2b ${ }^{c}, G C B a V^{b}$, RSI $^{b}$ & $38,37,24 \mathrm{kDa}$ \\
\hline LR 105 & GLRaV-1 ${ }^{\mathrm{a}}$, GLRaV-2 US ${ }^{\mathrm{b}}, \mathrm{GLRaV}^{-} 3^{\mathrm{a}}$ & $38,43 \mathrm{kDa}$ \\
\hline RSI & $\mathrm{GCBaV}^{\mathrm{b}}, \mathrm{GLR} \mathrm{VV}-2 \mathrm{FR}^{\mathrm{b}}, \mathrm{GLR} \mathrm{RV}-2 \mathrm{~b}^{\mathrm{c}}, \mathrm{RSI}^{\mathrm{b}}$ & $24 \mathrm{kDa}$ \\
\hline CB100 & 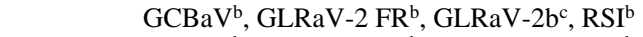 & $24 \mathrm{kDa}$ \\
\hline SJ & $\mathrm{GCBaV}^{\mathrm{b}}, \mathrm{GLR} \mathrm{VV}-2 \mathrm{FR}^{\mathrm{b}}, \mathrm{GLR} \mathrm{RV}-2 \mathrm{~b}^{\mathrm{c}}, \mathrm{RSI}^{\mathrm{b}}$ & $24 \mathrm{kDa}$ \\
\hline $\mathrm{MBF}$ & $\mathrm{GCBaV}^{\mathrm{b}}, \mathrm{GLRaV}^{-2} \mathrm{FR}^{\mathrm{b}}, \mathrm{GLR} \mathrm{RV}-2 \mathrm{~b}^{\mathrm{c}}, \mathrm{RSI}^{\mathrm{b}}$ & $24 \mathrm{kDa}$ \\
\hline PS & $\mathrm{GCBaV}^{\mathrm{b}}, \mathrm{GLR} \mathrm{VV}-2 \mathrm{FR}^{\mathrm{b}}, \mathrm{GLR} \mathrm{RV}-2 \mathrm{~b}^{\mathrm{c}}, \mathrm{RSI}^{\mathrm{b}}$ & $24 \mathrm{kDa}$ \\
\hline PS3 & 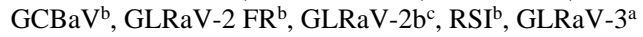 & $43,24 \mathrm{kDa}$ \\
\hline LR 101 & $\mathrm{GCBaV}^{\mathrm{b}}, \mathrm{GLRaV}-2 \mathrm{FR}^{\mathrm{b}}, \mathrm{GLRaV}-2 \mathrm{~b}^{\mathrm{c}}, \mathrm{RSI}^{\mathrm{b}}, \mathrm{GLRaV}-3^{\mathrm{a}}$ & $43,24 \mathrm{kDa}$ \\
\hline LR C & $\mathrm{GCBaV}^{\mathrm{b}}, \mathrm{GLRaV}^{-2} \mathrm{FR}^{\mathrm{b}}, \mathrm{GLRaV}-2 \mathrm{~b}^{\mathrm{c}}, \mathrm{RSI}^{\mathrm{b}}, \mathrm{GLRaV}^{-3^{\mathrm{a}}}$ & $43,24 \mathrm{kDa}$ \\
\hline LR 109 & $\mathrm{GCBaV}^{\mathrm{b}}, \mathrm{GLRaV}^{-2} \mathrm{FR}^{\mathrm{b}}, \mathrm{GLRaV}-2 \mathrm{~b}^{\mathrm{c}}, \mathrm{RSI}^{\mathrm{b}}, \mathrm{GLRaV}^{-3^{\mathrm{a}}}$ & $43,24 \mathrm{kDa}$ \\
\hline LR D & GLRaV-2 US ${ }^{\mathrm{b}}, \mathrm{GLRaV}-4^{\mathrm{b}}$ & $36 \mathrm{kDa}$ \\
\hline LR 106 & GLRaV-2 US ${ }^{\mathrm{b}}, \mathrm{GLRaV}-4^{\mathrm{b}}$ & $36 \mathrm{kDa}$ \\
\hline Healthy ${ }^{\mathrm{d}}$ & healthy ${ }^{\mathrm{b}}, \mathrm{GCBaV}^{\mathrm{b}}$ & No viral specific proteins \\
\hline
\end{tabular}

${ }^{a}$ Monoclonal or polyclonal antibodies.

b Polyclonal antibodies.

c Monoclonal antibodies.

${ }^{\mathrm{d}}$ Couderc 3309, Kober 5BB, Riparia Gloire, Malbec-vf, FC/2-vf.

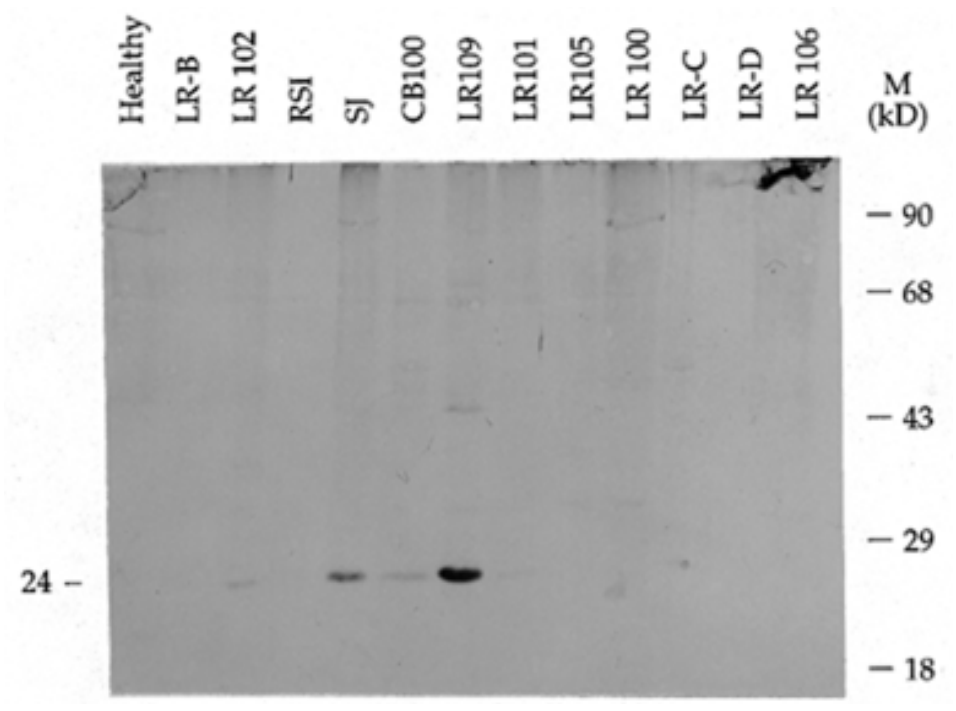

Fig. 3. Western blot assay of protein extracts using GLRaV-2 FR PA. The grapevine cultivars or isolates analyzed are indicated on the top of each lane. The molecular weight of size markers and the viral specific proteins are indicated on the sides of each blot. polypeptides seen in Figure 4C. The regenerated grapevine meristems have been acclimated and are presently grown in our research greenhouse to be used as negative controls in future experiments. All of the regenerated meristem cultures and greenhouse-grown plants were free of virusspecific polypeptides. These grapevine selections were designated FC/2-vf and Malbec-vf (Table 4).

\section{DISCUSSION}

Several leafroll and corky bark associated virus isolates were serologically characterized using ELISA and the WB assay. The ELISA sensitivity of GLRaV-2b MAb (not shown) and GLRaV-4 PA was low, and the GCBaV PA developed unacceptable non-specific ELISA reactivities (not shown). The later is consistent with the number of host bands observed in WB using GCBaV PA. The ELISA and WB results obtained question the utility of performing cross-absorption of PA to decrease their reactivity with host proteins. The low specificity and sensitivity of these antibodies combined with the uneven distribution of grapevine associated closteroviruses might explain the difficulty encountered in detecting these viruses using ELISA (18).

ELISA characterization of virus infections using PA can be complicated by reactions with host proteins as well as uncharacterized mixed virus infections. Our results suggest that the cultivar CA-5 used by Boscia et al. (2) to prepare GLRaV-2 US PA was also infected with other viruses. A doublet protein band of circa 37 to $38 \mathrm{kDa}$ was consistently observed in WB using the GLRaV-2 US PA and the LR 102 viral isolate. The $38-\mathrm{kDa}$ polypeptide from the doublet was identified as the GLRaV-1 capsid protein based on its reactivity with GLRaV-1 MAb and PA. The faster migrating polypeptide did not react with GLRaV-1 MAb or any of the other antisera tested.

In our study, the GLRaV-2 US PA (2) also showed weak reactivity with the 36kDa polypeptide associated with GLRaV-4 (11) and the 24-kDa polypeptide reported in association with GLRaV-2 (26). GLRaV-2 FR PA (26) showed reactivity with the $24-\mathrm{kDa}$ polypeptide and no reactivity to other viral specific polypeptides (Fig. 2D). These data suggest that the GLRaV-2 US PA reacts predominantly with higher molecular weight proteins, and the 24-kDa polypeptide was not detected in earlier experiments (2) due to the weak reactivity of the GLRaV-2 US PA to this polypeptide.

Our results are in partial agreement with Boscia et al. (1), who reported that the GLRaV-2 US PA reacted prevalently with GLRaV-1 isolates and weakly with GLRaV-2 isolates. Apparently, the European study (1) using ISEM did not include any American GLRaV isolates. Their inability to detect GLRaV-4 reactivity or to 
discover the 37- to $38-\mathrm{kDa}$ doublet might have been due to the limited amount of virus isolates tested.

We have recently developed MAb to the $37-\mathrm{kDa}$ polypeptide $(15,16)$. The MAb reacted to native and denatured conformations of the 37-kDa polypeptide associated with LR 102. Because the 37-kDa polypeptide did not react with the GLRaV7 PA developed in Italy (3), which also contains a $37-\mathrm{kDa}$ capsid protein, we have tentatively named our newly uncharacterized grapevine associated virus GLRaV-8 (data not shown). The new MAbs are presently being utilized to determine how widespread this virus strain is present in the United States (J. Monis and R. K. Bestwick, unpublished results).

Although the isolates designated LR-A and FC/2 reacted to GLRaV-1 MAb and GLRaV-2 US PA in ELISA, the WB assay data showed that these isolates are solely infected with GLRaV-1. These results show that when ELISA uses polyclonal antiserum raised against virus mixtures, results must be interpreted with caution.

The WB assay allows virus isolates to be distinguished on the basis of reactivity to different antisera. Because it is possible to correlate the presence of immuno-specific polypeptide bands with specific virus isolates, this assay confirms infection with different GLRaVs and GCBaV. Furthermore, the RG PA allowed the discrimination between viral and non-viral polypeptides. For example, host polypeptide bands were observed in the blots analyzed with $\mathrm{RG}$ antibodies as well as the blots analyzed with GCBaV (20) and Black Spanish polyclonal antisera (21). In addition, a host polypeptide of about $68 \mathrm{kDa}$ was observed in healthy and virus-infected material analyzed with the RG PA and GLRaV-2 US PA (2). The same host proteins were observed in extracts from vines from which the virus was eliminated using the apical meristem tissue culture method.

Using the WB assay, the RSI-24 $\mathrm{kDa}$ PA, GLRaV-2 FR PA, GLRaV-2b MAb, and GCBaV PA all detected a 24-kDa viral-specific polypeptide in RSI, SJ, CB 100, LR 101, and LR 109 isolates, suggesting that the viruses with $24 \mathrm{kDa}$ molecular weight coat proteins are serologically related. Others have reported the possible serological relationship between GLRaV-2, $-2 b$ and GCBaV $(8,21)$. Recently, Boscia et al. (1) suggested that GCBaV and GLRaV-2b are identical to the GLRaV-2 isolate identified in France. Sequence analyses of the nucleic acid of these virus isolates will determine how these virus isolates are related.

A number of field-grown vines infected with viruses with a coat protein of approximately $24 \mathrm{kDa}$ were asymptomatic when grafted onto the AXR-1 and St. George rootstocks. When these virus-infected scions were grafted onto phylloxeraresistant cultivars such as $5 \mathrm{C}, \mathrm{SO} 4, \mathrm{Cd}$
3309 , or RG, severe rootstock-scion incompatibility symptoms developed (J. Monis and R. K. Bestwick, unpublished). These observations show the importance of correct virus identification prior to grafting of scion material. In our hands, the only reliable rapid method to detect the $24-\mathrm{kDa}$ polypeptide associated with RSI is the WB assay.

We have shown that mixed infections of grapevine associated closteroviruses are common. Corky bark-, RSI-, and GLRaV-
$2 \mathrm{~b}$-specific polypeptides were detected in plants infected with GLRaV-2, -3, GCBaV, and vines showing RSI. GLRaV-1 was found in vines infected with GLRaV-3. However, vines with apparent single infections of GLRaV-1 (FC/2, LR-A), GLRaV-3 (CS/8; 18), and GLRaV-4 (LR-D, LR 106) were also identified. Graft-inoculation studies between single and multiple infections will provide information on the interactions between these viruses with respect to symptom expression and disease devel-

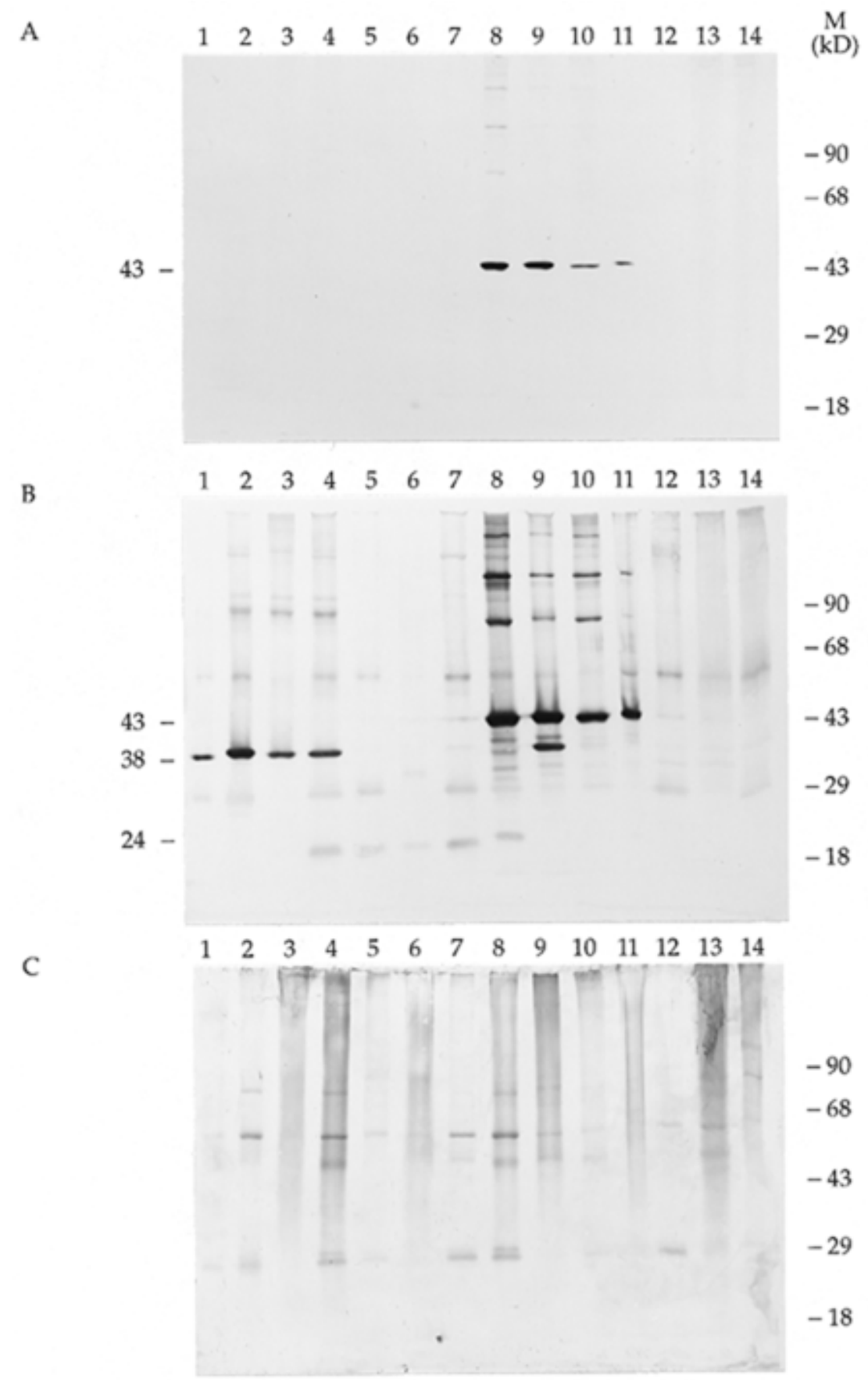

Fig. 4. Western blot assay of protein extracts using the following: GLRaV-3 MAb (A); Black Spanish PA (B); healthy grape PA (C). The grapevine cultivars or isolates analyzed are: lanes 1, FC/2; lanes 2, LR-A; lanes 3, LR-B; lanes 4, LR 102; lanes 5, RSI; lanes 6, SJ; lanes 7, CB 100; lanes 8, LR 109; lanes 9, LR 105; lanes 10, LR 101; lanes 11, LR-C; lanes 12, LR-D; lanes 13, LR 106; lanes 14, healthy. The molecular weight of size markers and the viral specific proteins are indicated on the sides of each blot. 
opment. It is possible that certain virus combinations might intensify symptom and disease development.

Although the WB assay is not a new technique, it has not been used to diagnose grapevine viruses. The WB assay is routinely used in our laboratory to confirm questionable ELISA results and to detect viruses associated with RSI. The disadvantages of the WB assay are the requirements of preparing concentrated virus extracts and using characterized viral isolates and antibodies. We believe that these disadvantages are outweighed by the reliable detection of viruses that otherwise would remain undetected until an infected scion is grafted onto an incompatible rootstock cultivar.

Future research will focus on the molecular and serological characterization of the described viruses. Sequence analyses of the viral nucleic acid and reactivity to panels of monoclonal antibodies will further elucidate the relatedness of these grapevine associated closteroviruses. For example, we will be able to determine if closterovirus-like particles with coat protein subunits in the range of 24 to $43 \mathrm{kDa}$ should be grouped within the closterovirus group or with other groups, based on refined molecular and serological characteristics. The information obtained from molecular studies should also allow the rationalization of the nomenclature of the viral isolates and antisera used for the diagnosis of grapevine rootstock scion incompatibility, leafroll, and corky bark diseases.

\section{ACKNOWLEDGMENTS}

This work was supported in part by a USDA SBIR grant (94-33610-0078). We thank the individuals listed in Table 2 for providing antibodies used in our studies; P. Gugerli and M. E. Ramel for assistance in performing ISEM in various samples; M. Benelli, X. Good, B. Berger, and F. Negru for excellent technical assistance; R. Hagen for help in the grapevine plant propagation; $\mathrm{K}$. Lawrence and J. Dieter for help in figure preparation; and R. Hamilton, V. Dolja, K. Eastwell, and M. Kramer for carefully reviewing the manuscript.

\section{LITERATURE CITED}

1. Boscia, D., Grief, C., Gugerli, P., Martelli, G. P., Walter, B., and Gonsalves, D. 1995. No- menclature of grapevine leafroll-associated putative closteroviruses. Vitis 34:171-175.

2. Boscia, D., Hu, J. S., Golino, D. A., and Gonsalves, D. 1990. Characterization of grape leafroll associated closteroviruses (GLRaV) serotype II and comparison with GLRaV III. Phytopathology 80:117.

3. Choueiri, E., Boscia, D., Digiaro, M., Castellano, M. A., and Martelli, G. P. 1996. Some properties of a hitherto undescribed filamentous virus of the grapevine. Vitis 35:91-93.

4. Golino, D. A. 1992. The Davis grapevine virus collection. Am. J. Enol. Vitic. 43:200205.

5. Golino, D. A. 1993. Potential interactions between rootstocks and grapevine latent viruses. Am. J. Enol. Vitic. 44: 148-152.

6. Golino D. A., Uyemoto, J., and Goheen, A. 1992. Leafroll and Corky Bark. Pages 101106 in: Grape Pest Management, UC Division of Agriculture and Natural Resources Press.

7. Gonsalves, D., Trujillo, E., and Hoch, H. C 1986. Purification and some properties of a virus associated with cardamom mosaic virus, a new member of the potyvirus group. Plant Dis. 70:65-69.

8. Gugerli, P., and Ramel, M. E. 1993. Grapevine leafroll associated virus II analyzed by monoclonal antibodies. Extended abstracts of the 11th Meeting of the International Council for the study of Viruses and Virus Diseases of the Grapevine, Montreux, Switzerland. September 6-9, 1993. Federal Agricultural Research Station of Changins, CH-1260 Nyon, Switzerland.

9. Harlow, E., and Lane, D. 1988. Antibodies, A Laboratory Manual. Cold Spring Harbor Laboratory Publications, Cold Spring Harbor, NY.

10. Hu, J. S., Gonsalves, D., Boscia, D., and Namba, S. 1990. Use of monoclonal antibodies to characterize grapevine leafroll associated closteroviruses. Phytopathology 80:920925.

11. Hu, J. S., Gonsalves, D., and Teliz, D. 1990. Characterization of closterovirus-like particles associated with grapevine leafroll disease. J. Phytopathol. 128:1-14.

12. Koruza, B., and Jelaska, S. 1993. Influence of meristem culture and virus elimination on phenotypical modifications of grapevine (Vitis vinifera L., cv. Refosk) Vitis 32:59-60.

13. Laemmli, U. K. 1970. Cleavage of structural proteins during the assembly of the head of bacteriophage T4. Nature 227:680-685

14. Martelli, G. P. 1993. Leafroll. Pages 37-44 in: Graft-transmissible Diseases of Grapevines. Handbook for Detection and Diagnosis. G. P. Martelli, ed. ICVG/FAO. Rome.

15. Monis, J., Berger, B, and Bestwick, R. 1996.
Production of antibodies specific to a 37 $\mathrm{kDa}$ polypeptide associated with grapevine leafroll associated virus. Am. J. Enol. Vitic. 47:351.

16. Monis, J., Berger, B, and Bestwick, R. 1996. Serological characterization of grapevine-associated closteroviruses. Proceedings of the Xth International Congress of Virology, Jerusalem, Israel, 11-16 August, 1996.

17. Monis, J., Bestwick, R. and Stamp, J. 1995. Detection of grapevine-associated-closteroviruses by a sensitive Western blot immunoassay. Am. J. Enol. Vitic. 46:404.

18. Monis, J., and Bestwick, R. K. 1996. Detection and localization of grapevine leafroll associated closteroviruses in greenhouse and tissue culture grown grapevines. Am. J. Enol. Vitic 47:199-205.

19. Murashige, T., and Skoog, F. 1962. A revised medium for rapid growth and bioassays with tobacco tissue cultures. Physiol. Plant. 15:473-497.

20. Namba, S., Boscia, D., Azzam, O., Maixner, M., Hu, J. S., Golino, D., and Gonsalves, D. 1991. Purification and properties of closterovirus-like particles associated with grapevine corky bark disease. Phytopathology 81:964-970.

21. Pietersen, G., and Kasdorf, G. G. F. 1993. Use of IEM for the detection of the viruses of the grapevine leafroll complex in South Africa. Extended abstracts of the 11th Meeting of the International Council for the study of Viruses and Virus Diseases of the Grapevine, Montreux, Switzerland. September 6-9, 1993. Federal Agricultural Research Station of Changins, CH-1260 Nyon, Switzerland.

22. Rowhani, A., and Golino, D. A. 1995. ELISA test reveals new information about leafrol disease. Calif. Agric. 49:26-29.

23. Towbin, $\mathrm{H}$, Staehelen, $\mathrm{T}$, and Gordon, J. 1979. Electrophoretic transfer of proteins from polyacrylamide gels to nitrocellulose sheets: Procedures and some applications. Proc. Natl. Acad. Sci. USA. 76:4350-4354.

24. Weber, E., Golino, D., and Rowhani, A. 1993. Leafroll disease in grapevines Practical Winery and Vineyard. March/April : 21-25.

25. Zee, F., Gonsalves, D., Goheen, A., Kim, K S., Pool, R., and Lee, R. F. 1987. Cytopathology of leafroll-diseased grapevines and the purification and serology of associated closterovirus-like particles. Phytopathology 77:1427-1434.

26. Zimmerman, D., Bass, P., Legin, R., and Walter, B. 1990. Characterization and serological detection of four closterovirus particles associated with leafroll disease on grapevine. J. Phytopathol. 130:205-218. 